\title{
Peranan Motivasi Kerja, Lingkungan Kerja, Dan Pengalaman Kerja Terhadap Kin- erja Karyawan Dinas Pendapatan Daerah Kabupaten Jember
}

\section{(The Role Of Motivation, Work Environment, And Work Experiences Of The Performances Of Employees Department Of Local Revenue Of Jember District)}

\author{
Mohammad Rizky Zakaria, Sampeadi ${ }^{1}$, Susanti Prasetyaningtyas \\ Jurusan Manajemen, Fakultas Ekonomi dan Bisnis, Universitas Jember (UNEJ) \\ Jln. Kalimantan 37, Jember 68121 \\ E-mail: lalananaku@gmail.com
}

\begin{abstract}
Abstrak
Penelitian ini bertujuan untuk mengetahui dan menganalisis: (1) peranan motivasi kerja terhadap kinerja karyawan Dinas Pendapatan Daerah Kabupaten Jember, (2) peranan lingkungan kerja terhadap kinerja karyawan Dinas Pendapatan Daerah Kabupaten Jember, (3) peranan pengalaman kerja terhadap kinerja Dinas Pendapatan Daerah Kabupaten Jember, dan (4) peranan motivasi kerja, lingkungan kerja, dan pengalaman kerja terhadap kinerja Dinas Pendapatan Daerah Kabupaten Jember. Pendekatan riset yang digunakan dalam penelitian ini adalah kuantitatif. Populasi yang ada pada Dinas Pendapatan Daerah Kabupaten jember sebanyak 261 orang. Sampel yang digunakan sebanyak 73 orang dan teknik pengambilan sampel menggunakan metode purposive sampling. Metode analisis data yang digunakan dalam penelitian ini adalah analisis regresi linier berganda. Hasil pengujian hipotesis yang dilakukan menunjukkan bahwa: (1) motivasi kerja berperan positif terhadap kinerja karyawan Dinas Pendapatan Daerah Kabupaten Jember, (2) lingkungan kerja berperan positif terhadap kinerja karyawan Dinas Pendapatan Daerah Kabupaten Jember, (3) pengalaman kerja berperan positif terhadap kinerja karyawan Dinas Pendapatan Daerah Kabupaten Jember, dan (4) motivasi kerja, lingkungan kerja, dan pengalaman kerja berperan positif terhadap kinerja karyawan Dinas Pendapatan Daerah Kabupaten Jember.
\end{abstract}

Kata Kunci: Kinerja Kerja, Lingkungan Kerja, Motivasi Kerja, Pengalaman Kerja

\begin{abstract}
This study aimed to know and analyze: (1) the role of motivation work of the performance of employees department of local revenue of Jember District, (2) the role of work environment of the performance of employees department of local revenue of Jember District, (3) the role of work experiences of the performance of employees department of local revenue of Jember District, and (4) the role of motivation work, work environment, and work experiences of the performance of employees department of local revenue of Jember District. The approach of the research which used in this research was quantitative. The population department of local revenue of Jember District as much as 261 people. Sample used as many as 73 people and technique the sample collection uses the method purposive sampling. The method of analysis of the data used in this research was linear regression analysis multiple. The results of the testing of hypothesis done show that: (1) motivation work has a positive role in employee's performance department of local revenue of Jember District, (2) work environment has a positive role in employee's performance department of local revenue of Jember District, (3) work experience has a positive role in employee's performance department of local revenue of Jember District, (4) motivation work, work environment, and work experience has a positive role in employee's performance department of local revenue of Jember District.
\end{abstract}

Keywords: Employee Performance, Work Environment, Motivation Work, Work Experience

\section{Pendahuluan}

Birokrat merupakan salah satu unsur kekuatan daya saing bangsa yang harus memiliki kinerja tinggi demi pencapaian tujuan pemerintah. Namun, kualitas dan kinerja birokrasi dalam memberikan pelayanan publik masih kurang dari harapan serta masih belum tercipta pelayanan publik yang berorientasi kepada kebutuhan masyarakat. Berbagai upaya untuk meningkatkan kinerja terus dilakukan oleh seluruh instansi pemerintah. Upaya tersebut dilakukan untuk meningkatkan hasil kerja yang diharapkan dan sesuai dengan program pemerintah yang telah direncanakan. Salah satu cara untuk meningkatkan kinerja yaitu dengan cara meningkatkan kualitas sumber daya manusianya. Untuk meningkatkan kinerja karyawan, organisasi harus mampu menciptakan kondisi yang dapat mendorong karyawan untuk meningkatkan kinerjanya secara optimal.

Salah satu cara untuk mewujudkan tujuan organisasi yaitu dengan memiliki karyawan yang memiliki kinerja yang baik. Kinerja karyawan merupakan hasil kerja yang dicapai seseorang dalam melaksanakan tugas sesuai dengan tanggung jawab yang telah diberikan. Pengukuran kinerja penting dilakukan karena berguna sebagai acuan untuk meningkatkan kinerja organisasi agar lebih baik lagi di masa mendatang. Menurut Kuswandi (2004:27) kinerja dipengaruhi oleh beberapa faktor antara lain kepuasan karyawan, kemampuan karyawan, motivasi, lingkungan kerja, serta kepemimpinan. Untuk mempertahankan kinerja karyawan adalah dengan memperhatikan faktor - faktor yang dapat mempengaruhi kinerja karyawan. Apabila kinerja karyawan tidak diperhatikan tentu akan mempengaruhi hasil kerja yang dilakukan.

1 Corresponding Author 
Salah satu upaya untuk meningkatkan kinerja karyawan yaitu dengan memberikan motivasi kerja. Motivasi merupakan faktor yang dapat mendorong karyawan untuk meningkatkan kinerjanya. Menurut Hasibuan (2007:95) motivasi kerja adalah pemberia $n$ daya penggerak yang menciptakan kegairahan kerja seseorang, agar mereka mau bekerja sama, bekerja efektif dan berintegrasi dengan segala daya dan upayanya untuk penciptaan kepuasan. Memotivasi karyawan dilakukan dengan memberikan tanggung jawab dan kesempatan yang luas bagi karyawan untuk mengambil keputusan dalam menyelesaikan pekerjaannya. Motivasi menjadi sangat penting karena dengan motivasi diharapkan setiap karyawan mau bekerja keras dan antusias. Motivasi akan memberikan insipirasi, dorongan, semangat kerja bagi karyawan sehingga terjalin hubungan kerja yang baik antara karyawan dan pimpinan sehingga tujuan organisasi dapat tercapai.

Sebagai aparatur pemerintahan, Pegawai Negeri Sipil atau PNS harus selalu bekerja dan melayani masyarakat semaksimal dan seefisien mungkin agar kebutuhan masyarakat dapat segera terpenuhi. Selain itu, Pegawai Negeri juga berkewajiban menjadi contoh dalam melaksanakan dan mentaati peraturan dan perundangundangan yang berlaku dalam melaksanakan tugas kedinasannya. Pemberian tugas kedinasan merupakan pemberian kepercayaan dari atasan kepada karyawan untuk menyelesaikan tugas dengan harapan bahwa tugas itu dilaksanakan dengan baik.

Dinas pendapatan daerah atau yang dikenal dengan sebutan Dispenda atau Dipenda adalah organisasi yang memiliki tanggung jawab dalam pemungutan pendapatan daerah melalui pengkoordinasian dan pemungutan pajak, retribusi, bagi hasil pajak, dana perimbangan, evaluasi dan monitoring serta pengendalian pelaksanaan pemungutan pajak yang diberikan oleh Bupati. Oleh karena itu, dibutuhkan kinerja yang baik dari karyawan, sehingga urusan pemerintah kabupaten dapat terlaksana dengan baik.

Motivasi langsung yang diberikan untuk karyawan yaitu pemberian reward yang berupa honor tim kegiatan. Selain itu ada pemberian gaji 13 dan mulai tahun 2016 ada pemberian Tunjangan Hari Raya (THR) bagi karyawan dengan syarat melampirkan Sasaran Kerja Pegawai (SKP) tahun sebelumnya. Adapun motivasi tidak langsung yang diberikan untuk karyawan yaitu fasilitas komputer untuk tiap karyawan dan fasilitas-fasilitas lain untuk menunjang pekerjaan mereka. Namun beberapa pegawai masih kurang memiliki keterampilan yang cukup dalam mengoperasikan komputer dengan baik, sehingga masih harus meminta bantuan kepada karyawan lain yang mengakibatkan beberapa pekerjaan tidak dapat diselesaikan tepat pada waktunya. Dalam hal ini, pengalaman kerja sangat berperan untuk menyeselesaikan permasalahan yang terjadi. Karyawan yang lebih lama bekerja pada Dinas Pendapatan Daerah dapat membantu karyawan yang masih baru dan tidak mengerti bagaimana menggunakan fasilitas yang disediakan oleh Dinas Pendapatan Daerah sebagai penunjang pekerjaannya.

Selain itu, kondisi ruang kerja seperti meja kantor antara karyawan satu dengan karyawan lainnya juga terlalu sempit, sehingga karyawan tidak leluasa bekerja. Juga pengaturan suhu air conditioner atau (AC) juga tidak terlalu bagus. Keadaan lingkungan kerja yang seperti itu membuat karyawan terganggu dan merasa kurang nyaman dalam bekerja.

Penelitian terdahulu yang dilakukan dan memiliki keterkaitan dengan penelitian ini adalah: penelitian yang dilakukan oleh M Harlie (2010) dengan hasil penelitian yakni motivasi kerja berperan positif terhadap kinerja karyawan. Munparidi (2012) dengan hasil penelitian menunjukkan bahwa lingkungan kerja berperan positif terhadap kinerja karyawan. Fajarani (2012) dengan hasil penelitian yakni pengalaman kerja memiliki peranan positif terhadap kinerja karyawan.

Hipotesis yang diajukan dalam penelitian ini antara lain: (1) motivasi berperan positif terhadap kinerja karyawan Dinas Pendapatan Daerah Kabupaten Jember, (2) lingkungan kerja berperan positif terhadap kinerja karyawan Dinas Pendapatan Daerah Kabupaten Jember, (3) pengalaman kerja berperan positif terhadap kinerja karyawan Dinas Pendapatan Daerah Kabupaten Jember, (4) motivasi kerja, lingkungan kerja, dan pengalaman kerja secara bersama-sama berperan positif terhadap kinerja karyawan Dinas Pendapatan Daerah Kabupaten Jember.

Rumusan masalah dalam penelitian ini diantaranya: (1) apakah motivasi kerja berperan positif terhadap kinerja karyawan Dinas Pendapatan Daerah Kabupaten Jember?, (2) apakah lingkungan kerja berperan positif terhadap kinerja karyawan Dinas Pendapatan Daerah Kabupaten Jember?, (3) apakah pengalaman kerja berperan terhadap kinerja karyawan Dinas Pendapatan Daerah Kabupaten Jember?, dan (4) apakah motivasi kerja, lingkungan kerja, pengalaman kerja secara bersama-sama berperan positif terhadap kinerja karyawan Dinas Pendapatan Daerah Kabupaten Jember?

Tujuan penelitian ini adalah untuk mengetahui dan menganalisis: (1) peranan motivasi kerja terhadap kinerja karyawan Dinas Pendapatan Daerah Kabupaten Jember, (2) peranan lingkungan kerja terhadap kinerja karyawan Dinas Pendapatan Daerah Kabupaten Jember, (3) peranan pengalaman kerja terhadap kinerja karyawan Dinas Pendapatan Daerah Kabupaten Jember, dan (4) peranan motivasi kerja, lingkungan kerja, dan pengalaman kerja secara bersama-sama terhadap kinerja karyawan Dinas Pendapatan Daerah Kabupaten Jember.

\section{Metode}

\section{Rancangan Penelitian}

Rancangan penelitian dalam penelitian ini adalah explanatory research. Menurut Arikunto (2006:12) explanatory research adalah penelitian yang menjelaskan hubungan kausal dan menguji keterkaitan antara beberapa variabel melalui pengujian hipotesis atau penelitian penjelasan.

\section{Jenis dan Sumber Data}

Jenis data yang digunakan dalam penelitian ini adalah bersifat kuantitatif yaitu data berbentuk angka-angka, baik secara langsung digali dari hasil penelitian maupun hasil pengelolahan data kualitatif menjadi data kuantitatif dengan memberikan skor sesuai skala likert untuk responden. Setelah data diperoleh, maka data akan diolah dengan menggunakan 
software IBM SPSS 23 Statistic for Windows yang selanjutnya akan dianalisis. Sumber data yang digunakan dalam penelitian ini diantaranya data primer yang berasal dari sebaran kuisioner dan data sekunder yang berasal dari artikel, jurnal, buku-buku dan situs internet yang berhubungan dengan penelitian yang dilakukan

\section{Populasi dan Sampel}

Populasi dalam penelitian ini adalah seluruh karyawan Dinas Pendapatan Daerah Kabupaten Jember sebanyak 261 orang. Teknik pengambilan sampel pada penelitian ini menggunakan purposive sampling, yang mana sampel dipilih berdasarakan kriteria-kriteria tertentu, sehingga diperoleh sebanyak 73 orang sebagai responden.

\section{Metode Analisis Data}

Metode analisis data dalam penelitian ini menggunakan analisis regresi linier berganda dengan bantuan software IBM SPSS 23 for Windows untuk mengolah data yang telah didapat.

\section{Hasil dan Pembahasan}

\section{Hasil}

Karakteristik Responden

a. Karakteristik Responden Berdasarkan Usia

\section{Rekapitulasi Responden Berdasarkan Usia}

\begin{tabular}{ccc}
\hline Usia & Jumlah & Persentase $(\%)$ \\
\hline $30-40$ tahun & 46 & 63,01 \\
$41-50$ tahun & 23 & 31,51 \\
$51-60$ tahun & 4 & 5,48 \\
\hline Total & 73 & 100
\end{tabular}

Sumber: Dinas Pendapatan Daerah Kabupaten Jember, 2016.

Tabel 1 menunjukkan bahwa dari 73 responden terdapat 46 orang atau $63,01 \%$ yang berusia antara 30-40 tahun, 23 orang atau $31,51 \%$ yang berusia antara $41-50$ tahun dan 4 orang atau 5,48\% yang berusia antara 51-60 tahun.

b. Karakteristik Responden Berdasarkan Jenis Kelamin

Tabel 2. Rekapitulasi Responden Berdasarkan Jenis Kelamin

\begin{tabular}{ccc}
\hline Jenis Kelamin & Jumlah & Persentase (\%) \\
\hline Laki-laki & 48 & 65,76 \\
Perempuan & 25 & 34,24 \\
\hline Total & 73 & 100
\end{tabular}

Sumber: Dinas Pendapatan Daerah Kabupaten Jember, 2016.

Tabel 2 menunjukkan bahwa dari 73 responden terdapat 48 orang atau $65,76 \%$ adalah laki-laki dan 25 orang atau 34,24\% adalah perempuan. Dari hasil yang diperoleh menunjukkan bahwa sebagian besar karyawan Dinas Pendapatan Daerah Kabupaten Jember merupakan laki-laki.

c. Karakteristik Responden Berdasarkan Tingkat Pendidikan

Tabel 3. Rekapitulasi Responden Berdasarkan Tingkat Pendidikan

\begin{tabular}{ccc}
\hline Tingkat Pendidikan & Jumlah & Persentase (\%) \\
\hline SLTA/Sederajat & 17 & 23,29 \\
Diploma-3/D3 & 14 & 19,18 \\
Strata-1/S1 & 38 & 52,05 \\
Strata-2/S2 & 4 & 5,48 \\
Strata-3/S3 & - & - \\
\hline Total & 73 & 100
\end{tabular}

Sumber: Dinas Pendapatan Daerah Kabupaten Jember, 2016.

Tabel 3 menunjukkan bahwa dari 73 responden terdapat 17 orang atau 23,29\% yang berpendidikan SLTA/Sederajat, 12 orang atau 19,18\% berpendidikan Diploma-3 (D3), 38 orang atau $52,05 \%$ berpendidikan Strata-1 (S1), 4 orang atau 5,48\% berpendidikan Strata-2 (S2) dan 0 orang atau $0 \%$ berpendidikan Strata-3 (S3).

d. Karakteristik Responden Berdasarkan Lama Bekerja

Tabel 4. Rekapitulasi Responden Berdasarkan Lama Bekerja

\begin{tabular}{ccc}
\hline Lama Bekerja & Jumlah & Persentase $(\%)$ \\
\hline$<5$ Tahun & 16 & 21,92 \\
$5-10$ Tahun & 31 & 42,46 \\
$>10$ Tahun & 26 & 35,62 \\
\hline Total & 73 & 100
\end{tabular}

Sumber: Dinas Pendapatan Daerah Kabupaten Jember, 2016.

Tabel 4 menunjukkan bahwa dari 73 responden terdapat 16 orang atau $21,92 \%$ yang telah bekerja $<5$ tahun, 31 orang atau $42,46 \%$ telah bekerja antara 5-10 tahun dan 26 orang atau $35,62 \%$ telah bekerja $>10$ tahun.

\section{Uji Analisis Regresi Linier Berganda}

Dalam menganalisis adanya pengaruh yang terjadi antara variabel bebas terhadap variabel terikat peneliti menggunakan bantuan software IBM SPSS 23 for Windows dengan hasil pengujian pengaruh langsung sebagai berikut:

Tabel 5. Hasil Uji Analisis Regresi Linier Berganda

\begin{tabular}{ccccc}
\hline $\begin{array}{c}\text { Variabel } \\
\text { Independen }\end{array}$ & Beta & Sig & A & Keterangan \\
\hline Konstan & 2,379 & - & - & - \\
$\begin{array}{c}\text { Motivasi Kerja } \\
\text { Lingkungan } \\
\text { Kerja }\end{array}$ & 0,276 & 0,001 & $5 \%$ & $\begin{array}{c}\text { Positif dan } \\
\text { Signifikan }\end{array}$ \\
$\begin{array}{c}\text { Pengalaman } \\
\text { Kerja }\end{array}$ & 0,622 & 0,000 & $5 \%$ & $\begin{array}{c}\text { Positif dan } \\
\text { Signifikan } \\
\text { Positif } \\
\text { dan }\end{array}$ \\
\hline
\end{tabular}

Sumber: data primer, 2016.

Berdasarkan hasil uji analisis regresi linier berganda di atas maka diperoleh hasil persamaan regresi linier berganda:

$\mathrm{Y}=2,379+0,276 \mathrm{X}_{1}+0,622 \mathrm{X}_{2}+0,133 \mathrm{X}_{3}+\mathrm{e}$

Keterangan:

a. Nilai Konstanta 
Berdasarkan Tabel 5 di atas, pada kolom coefficientst $\mathrm{B}$ nilai constants sebesar 2,739, nilai ini menunjukkan jika nilai motivasi kerja, lingkungan kerja, dan pengalaman kerja bernilai 0 dan yang lain dianggap konstan maka kinerja karyawan bernilai 2,739.

\section{b. Motivasi Kerja (X1)}

Nilai koefisien dari variabel gaya kepemimpinan transformasional adalah bernilai positif 0,276 yang menjelaskan bahwa setiap kenaikan satu satuan variabel tersebut, akan meningkatkan kepuasan kerja sebesar 0,276.

\section{c. Lingkungan Kerja (X2)}

Nilai koefisien dari variabel lingkungan adalah bernilai positif 0,622 yang menjelaskan bahwa setiap kenaikan satu satuan variabel tersebut, akan meningkatkan kepuasan kerja sebesar 0,622 .

\section{d. Pengalaman Kerja (X3)}

Nilai koefisien dari variabel budaya organisasi adalah bernilai positif 0,133 yang menjelaskan bahwa setiap kenaikan satu satuan variabel tersebut, akan meningkatkan kepuasan kerja sebesar 0,133 .

Uji Hipotesis

a. Uji Statistik $\mathrm{t}$

Tabel 6. Hasil Uji Statistik t

\begin{tabular}{lccc}
\hline Variabel Independen & t hitung & t tabel & Sig \\
\hline Motivasi Kerja & 3,561 & 1,993 & 0,001 \\
Lingkungan Kerja & 8,579 & 1,993 & 0,000 \\
Pengalaman Kerja & 2,084 & 1,993 & 0,041
\end{tabular}

Sumber: data primer, 2016.

Berdasarkan Tabel 6 Hasil Uji Statistik t diatas variabel $\mathrm{X}_{1}$ yaitu motivasi kerja dengan $\mathrm{t}$ hitung sebesar 3,561 $>\mathrm{t}$ tabel sebesar 1,993, yang berarti thitung $>\mathrm{t}$ tabel, maka $\mathrm{H}_{0}$ ditolak dan $\mathrm{H}_{\mathrm{a}}$ diterima, jadi variabel motivasi kerja secara parsial memiliki peranan nyata terhadap variabel kinerja karyawan. Variabel $\mathrm{X}_{2}$ yaitu lingkungan kerja dengan $\mathrm{t}$ hitung sebesar $8,579>\mathrm{t}$ tabel sebesar 1,993, yang berarti $\mathrm{t}$ hitung $>\mathrm{t}$ tabel, maka $\mathrm{H}_{0}$ ditolak dan $\mathrm{H}_{\mathrm{a}}$ diterima jadi variabel lingkungan kerja memiliki peranan nyata terhadap variabel kinerja karyawan. Selanjutnya variabel $\mathrm{X}_{3}$ yakni pengalaman kerja dengan $\mathrm{t}$ hitung sebesar 2,084 $>\mathrm{t}$ tabel sebesar 1,993, yang berarti $\mathrm{t}$ hitung $>\mathrm{t}$ tabel, maka $\mathrm{H}_{0}$ ditolak dan $\mathrm{H}_{\mathrm{a}}$ diterima jadi variabel pengalaman kerja secara parsial memiliki peranan nyata terhadap variabel kinerja karyawan.

b. Uji Statistik F

Tabel 7. Hasil Uji Statistik F

\begin{tabular}{cccc}
\hline Variabel & F hitung & F tabel & Sig \\
\hline $\begin{array}{l}\text { Motivasi Kerja, } \\
\text { lingkungan kerja, dan } \\
\text { pengalaman kerja }\end{array}$ & 78,902 & 2,74 & 0,000 \\
\hline
\end{tabular}

Sumber: data primer, 2016
Berdasarkan hasil analisis regresi linier berganda pada tabel 7 diperoleh nilai $F$ 78,902 dengan nilai signifikansi 0,000 . Nilai $\mathrm{F}$ hitung lebih besar daripada $\mathrm{F}$ tabel yakni 678,902 > 2,74 dan nilai signifikansi lebih kecil dari 0,05. Nilai signifikansi yang lebih kecil daripada 0,05 hal ini berarti variabel motivasi kerja, lingkungan kerja dan pengalaman secara bersama-sama (simultan) memiliki pernanan terhadap variabel kinerja karyawan.

\section{Pembahasan}

\section{Peranan Motivasi Kerja Terhadap Kinerja Karyawan Dinas Pendapatan Daerah Kabupaten Jember}

Berdasarkan analisis regresi linier berganda yang telah dilakukan diketahui bahwa motivasi kerja berperan positif terhadap kinerja karyawan dengan nilai sebesar 0,276 pada tingkat kepercayaan 5\%. Serta hasil perolehan t hitung lebih besar dari t tabel $(3,561>1,993)$ maka $\mathrm{H}_{0}$ ditolak dan $\mathrm{Ha}$ diterima, sehingga dapat disimpulkan bahwa motivasi kerja berperan positif terhadap kinerja karyawan Dinas Pendapatan Daerah Kabupaten Jember. Peranan ini bersifat positif, artinya semakin tinggi motivasi kerja maka akan meningkatkan kinerja setiap karyawan.

Motivasi kerja adalah pemberian daya penggerak yang menciptakan kegairahan kerja seseorang, agar mereka mau bekerja sama, bekerja efektif dan berintegrasi dengan segala daya dan upayanya untuk penciptaan kepuasan (Hasibuan, 2007:95). Sedangkan menurut Uno (2010:71) motivasi kerja adalah salah satu faktor yang menentukan kinerja seseorang.

Motivasi kerja pada Dinas Pendapatan Daerah Kabupaten Jember memberikan kepuasan terhadap karyawannya. Motivasi yang dimaksud adalah motivasi langsung berupa reward honor tim kegiatan. Selain itu pemberian gaji 13 dan mulai tahun 2016 ada pemberian Tunjangan Hari Raya (THR) bagi karyawan dengan syarat melampirkan Sasaran Kerja Pegawai (SKP) tahun sebelumnya.

Hasil penelitian ini sejalan dengan penelitian terdahulu yang dilakukan oleh M Harlie (2010) mengenai disiplin kerja, motivasi kerja, dan pengembangan karir terhadap kinerja karyawan. Penelitian tersebut menunjukkan hasil bahwa peranan positif antara motivasi kerja terhadap kinerja karyawan.

\section{Peranan Lingkungan Kerja Terhadap Kinerja Karyawan Dinas Pendapatan Daerah Kabupaten Jember}

Berdasarkan analisis regresi linier berganda yang telah dilakukan, diketahui bahwa lingkungan kerja berperan positif terhadap kinerja karyawan dengan nilai sebesar 0,622 pada tingkat kepercayaan 5\%. Serta hasil perolehan t hitung lebih besar dari t tabel $(8,579>1,993)$ maka $\mathrm{H}_{0}$ ditolak dan $\mathrm{Ha}$ diterima, sehingga dapat disimpulkan bahwa lingkungan kerja berperan positif terhadap kinerja karyawan Dinas Pendapatan Daerah Kabupaten Jember. Peranan ini bersifat positif, artinya semakin baik lingkungan kerja maka kinerja karyawan tersebut akan meningkat.

Lingkungan kerja merupakan saranan penunjang kelancaran proses kerja, dimana kenyamanan dan keselamatan dalam bekerja juga sangat diperhitungkan dalam menciptakan suasana kerja yang kondusif dan menyenangkan bagi para 
karyawan sehingga dapat mendukung kinerja karyawan dalam melaksanakan aktivitas pekerjaannya. Menurut Saydam (2000:226) mendefinisikan lingkungan kerja sebagai "keseluruhan sarana prasarana kerja yang ada disekitar karyawan yang sedang melaksanakan pekerjaan yang dapat mempengaruhi pekerjaan itu sendiri”.

Lingkungan kerja pada Dinas Pendapatan Daerah Kabupaten Jember memberikan nilai positif terhadap kinerja karyawan. Lingkungan kerja yg dimaksud adalah lingkungan kerja yang berbentuk fisik maupun psikis (non fisik). Lingkungan kerja fisik meliputi tata ruang, rancangan perlatan, penerangan yang baik, pengaturan suhu dan sirkulasi udara, serta pengaturan kebisingan yang mengganggu. Sedangkan lingkungan kerja psikis meliputi keersamaan, hubungan baik antar rekan kerja, sikap atau perilaku karyawan, sifat atau karakteristik individu, dan keadaan emosi.

Namun, masih ada beberapa kendala yang dikeluhkan karyawan Dinas Pendapatan Daerah Kabupaten Jember mengenai penataan ruang kerja para karyawan yang dinilai terlalu sempit sehingga menganggu kenyamanan karyawan dalam bekerja.

Hasil penelitian ini sejalan dengan yang dilakukan oleh Munparidi (2012) mengenai kepemimpinan, motivasi kerja, dan lingkungan kerja terhadap kinerja karyawan. Penelitian tersebut menunjukkan bahwa lingkungan kerja berperan positif terhadap kinerja karyawan.

\section{Peranan Pengalaman Kerja Terhadap Kinerja Karyawan Dinas Pendapatan Daerah Kabupaten Jember}

Berdasarkan analisis regresi linier berganda yang telah dilakukan, diketahui bahwa pengalaman kerja berperan positif terhadao kinerja karyawan dengan nilai sebesar 0,133 pada tingkat kepercayaan $5 \%$. Serta hasil perolehan t hitung lebih besar dari t tabel $(2,084>1,993)$ maka $\mathrm{H}_{0}$ ditolak dan Ha diterima, sehingga dapat disimpulkan bahwa pengalaman kerja berperan positif terhadap kinerja karyawan Dinas Pendapatan Daerah Kabupaten Jember. Peranan ini bersifat positif, artinya semakin banyak pengalaman kerja maka kinerja karyawan tersebut akan meningkat.

Pengalaman kerja adalah sebagai suatu ukuran tentang lama waktu atau masa kerjanya yang telah ditempuh seseorang dalam memahami tugas - tugas suatu pekerjaan dan telah melaksanakannya dengan baik (Foster, 2001:40). Sedangkan menurut Elaine B Johnson (2007:228) menyatakan bahwa "pengalaman memunculkan potensi seseorang. Potensi penuh akan muncul bertahap seiring berjalannya waktu sebagai tanggapan terhadap bermacam-macam pengalaman".

Pengalaman kerja yang dimiliki akan membantu karyawan untuk menyelesaikan pekerjaannya dengan baik sehingga tidak menghambat pekerjaan yang telah ditentukan. Selain itu, orang yang berpengalaman akan semakin lincah dan cepat dalam menyelesaikan masalah yang terjadi.

Hasil penelitian ini sejalan dengan yang dilakukan oleh Eka Fajarani (2012) mengenai pengalaman kerja, kepemimpinan transformasional, dan loyalitas karyawan. Penelitian tersebut menunjukkan bahwa pengalaman kerja berperan positif terhadap kinerja karyawan.

Peranan Motivasi Kerja, Lingkungan Kerja, dan

\section{Pengalaman Kerja Terhadap Kinerja Karyawan}

Berdasarkan analisis regresi linier berganda yang telah dilakukan, diketahui bahwa motivasi kerja, lingkungan kerja dan pengalaman kerja secara bersama-sama (simultan) berperan positif terhadap kinerja karyawan dengan nilai $\mathrm{F}$ hitung lebih besar dari F tabel yaitu 78,902 > 2,74 pada tingkat kepercayaan 5\%.

Motivasi kerja, lingkungan kerja, dan pengalaman kerja yang ada pada karyawan Dinas Pendapatan Daerah Kabupaten Jember memberikan dampak positif terhadap peningkatan kinerja karyawan. Pekerjaan yang cukup padat bagi karyawan dapat menurunkan kinerja karyawan, sehingga dibutuhkan motivasi kerja baik secara positif maupun negatif. Kemudian dibutuhkan kondisi lingkungan kerja fisik dan lingkungan kerja non fisik yang baik dan pengalaman kerja yang cukup yang dimiliki oleh karyawan sehingga dapat meningkatkan kinerja karyawan pada Dinas Pendapatan Daerah Kabupaten Jember.

Hasil penelitian ini sejalan dengan yang dilakukan oleh Ragil Permansari (2013) mengenai motivasi kerja, lingkungan kerja, dan pengalaman kerja terhadap kinerja karyawan. Penelitian tersebut menunjukkan bahwa motivasi kerja, lingkungan kerja, dan pengalaman kerja memiliki peranan positif terhadap kinerja karyawan.

\section{Simpulan}

Berdasarkan pada penelitian yang telah dilakukan terhadap responden yakni karyawan Dinas Pendapatan Daerah Kabupaten Jember terdapat empat kesimpulan yakni: (1) Motivasi kerja berperan signifikan positif terhadap kinerja karyawan Dinas Pendapatan Daerah Kabupaten Jember, (2) Lingkungan kerja berperan signifikan positif terhadap kinerja karyawan Dinas Pendapatan Daerah Kabupaten Jember, (3) Pengalaman kerja berperan signifikan positif terhadap kinerja karyawan Dinas Pendapatan Daerah Kabupaten Jember, dan (4) Motivasi kerja, lingkungan kerja, dan pengalaman kerja secara bersama-sama (simultan) berperan terhadap kinerja karyawan Dinas Pendapatan Daerah Kabupaten Jember.

\section{Ucapan Terima Kasih}

Penulis mengucapkan banyak terimakasih kepada seluruh karyawan dan pimpinan Dinas Pendapatan Daerah Kabupaten Jember yang telah berpartisipasi dan turut membantu dalam penelitian ini sehingga penelitian ini dapat diselesaikan dengan baik.

\section{Referensi}

Arikunto, Suharsimi. 2006. Prosedur Penelitian Suatu Pendekatan Praktik. Jakarta: Rineka Cipta.

Elaine B. Johnson. 2007. Contextual teaching \& learning. Cetakan III. Diterbitkan oleh Penerbit MLC Jin.

Fajarani, Ni Putu Eka. Peranan Pengalaman Kerja dan Kepemimpinan Transformasional Terhadap Loyalitas Karyawan LPD Desa Adat Kedongan. Jurnal Manajemen Unud, Volume 4, No 4, Hal 930-942.

Foster, B. S., dan R. Karen. 2001. Pembinaan Untuk Meningkatkan Kinerja Karyawan. PPM Jakarta.

Harlie, M. 2010. Peranan Disiplin Kerja, Motivasi dan Pengembangan Karier Terhadap Kinerja Pegawai Negri Sipil pada Pemerintah Kabupaten Tabalong di Tanjung Kalimantan Selatan. Jurnal Manajemen dan Akuntansi, Oktober 2010, Volume 11, No 2. 
Hasibuan, Malayu S.P. 2007. Organisasi dan Motivasi Dasar Peningkatan Produktivitas. Jakarta: PT Bumi Aksara.

Kuswandi. 2004. Cara Mengukur Kepuasan Kerja. Jakarta. Elex Media. Komputindo

Munparidi. 2012. Peranan Kepemimpinan, Motivasi dan Lingkungan Kerja Terhadap Kinerja Karyawan Pada Perusahaan Daerah Air Minum Tirta Musi Kota Palembang. Jurnal Orasi Bisnis edisi VII.
Permansari, Ragil. 2013. Peranan Motivasi dan Lingkungan Kerja Terhadap Kinerja PT. AUGRAH RAHARJO Semarang. Jurnal Manajemen, Universitas Negeri Semarang.

Saydam, G.2000. Manajemen Sumber Daya Manusia. Jakarta: Djambatan.

Uno, Hamzah B. 2010. Teori Motivasi dan Pengukurannya (Analisis di Bidang Pendidikan). Jakarta: PT Bumi Aksara 